\title{
Features of the resource species Miscanthus sacchariflorus (Maxim.) Hack. when introduced in West Siberia
}

\author{
Yu.A. Gismatulina ${ }^{1} \otimes$, V.V. Budaeva ${ }^{1}$, G.V. Sakovich ${ }^{1}$, O.Yu. Vasilyeva², G.A. Zueva², A.S. Gusar ${ }^{3}$, O.V. Dorogina ${ }^{2}$ \\ ${ }^{1}$ Institute for Problems of Chemical and Energetic Technologies, SB RAS, Biysk, Russia \\ ${ }^{2}$ Central Siberian Botanical Garden, SB RAS, Novosibirsk, Russia \\ ${ }^{3}$ Novosibirsk State Agrarian University, Novosibirsk, Russia \\ 凶e-mail: julja.gismatulina@rambler.ru
}

Here we provide a scientific justification and experimental support for the choice of easily renewable cellulosic feedstock Miscanthus sacchariflorus (Maxim.) Hack. in order to obtain high-quality nutrient broths therefrom for bacterial cellulose biosynthesis. The plant life-forms promising for breeding were screened under introduction conditions at the Central Siberian Botanical Garden, SB RAS, and this study was thus aimed at investigating the full and reduced ontogenetic patterns; cellulose and noncellulosic contents, including lignin; and duraminization of vegetative (feedstock source) organs throughout the seasonal development. The full ontogenetic patterns of the plants grown from seeds that had been collected in native habitats were compared to show that $M$. sacchariflorus and $M$. sinensis Anderss. accessions are distinguished by longer being at the most vulnerable developmental stages: seedlings and plantlets. Hence, it is preferable to cultivate seedlings on protected ground, and plantations are advisable to establish with more stable cloned vegetative material. The chemical compositions of the whole plant, leaf and stem separately, from seven $M$. sacchariflorus harvests were examined to reveal a rise in cellulose content and a drop in noncellulosic content with plantation age. The Miscanthus stem was found to contain more cellulose than the leaf, regardless of the plant age. The overall cellulose content was $48-53 \%$, providing a rationale for studies of bacterial cellulose biosynthesis in a $M$. sacchariflorusderived nutrient medium. Since high lignin content is undesirable for technological processes concerned with biosynthesis of bacterial cellulose, we performed histochemical assays of transverse sections of the culms to monitor the seasonal course of lignification. Our results suggest that the specific time limits for harvesting the aboveground biomass as a feedstock be validated by histochemical data on the seasonal course of lignification of $M$. sacchariflorus sprouts. To sum up, the examined chemical composition of $M$. sacchariflorus grown in the Siberian climate conditions demonstrated its prospects as a source of glucose substrate, the basic component of good-quality nutrient media for biosynthesis of bacterial cellulose.

Key words: Miscanthus; Miscanthus sacchariflorus; ontogeny; chemical composition; cellulose; bacterial cellulose; histochemical analysis.

For citation: Gismatulina Yu.A., Budaeva V.V., Sakovich G.V., Vasilyeva O.Yu., Zueva G.A., Gusar A.S., Dorogina O.V. Features of the resource species Miscanthus sacchariflorus (Maxim.) Hack. when introduced in West Siberia. Vavilovskii Zhurnal Genetiki i Selektsii = Vavilov Journal of Genetics and Breeding. 2019;23(7):933-940. DOI $10.18699 /$ VJ19.569

\section{Особенности ресурсного вида Miscanthus sacchariflorus (Maxim.) Hack. при интродукции в Западной Сибири}

\author{
Ю.А. Гисматулина ${ }^{1}$ 囚, В.В. Будаева ${ }^{1}$, Г.В. Сакович ${ }^{1}$, О.Ю. Васимьева ${ }^{2}$ Г.А. Зуева ${ }^{2}$, А.С. Гусар ${ }^{3}$, О.В. Аорогина ${ }^{2}$

\footnotetext{
${ }^{1}$ Институт проблем химико-энергетических технологий Сибирского отделения Российской академии наук, Бийск, Россия

2 Центральный сибирский ботанический сад Сибирского отделения Российской академии наук, Новосибирск, Россия

${ }^{3}$ Новосибирский государственный аграрный университет, Новосибирск, Россия

凶e-mail: julja.gismatulina@rambler.ru
}

\begin{abstract}
В настоящей работе представлено научно-теоретическое обоснование и экспериментальное подтверждение выбора легковозобновляемого целлюлозосодержащего сырья - Miscanthus sacchariflorus (Maxim.) Hack. - с целью получения из него доброкачественных питательных сред для биосинтеза бактериальной целлюлозы. Отбор форм, перспективных для селекции, проводили в условиях интродукции Центрального сибирского ботанического сада Сибирского отделения Российской академии наук. Цель наших исследований - изучение онтогенеза, массовой доли целлюлозы и нецеллюлозных компонентов, включая лигнин, а также процессов одревеснения вегетативных (сырьевых) органов в течение сезонного развития. Сравнительный анализ особенностей онтогенеза полного типа у растений, выращенных из семян,
\end{abstract}




\begin{abstract}
собранных в естественных местообитаниях, показал, что образцы M. sacchariflorus и M. sinensis Anderss. отличаются продолжительным пребыванием в наиболее уязвимых онтогенетических состояниях - проростках и ювенильных растениях. Поэтому более успешное выращивание сеянцев лучше проводить в условиях защищенного грунта, а производственные площади целесообразно закладывать за счет более устойчивого вегетативного клонированного материала. При анализе химического состава растения в целом, а также листа и стебля отдельно семи урожаев M. sacchariflorus обнаружено, что по мере взросления плантации увеличивается массовая доля целлюлозы и уменьшается содержание нецеллюлозных компонентов. Выявлено, что вне зависимости от возраста растения в стебле мискантуса присутствует более высокая массовая доля целлюлозы, чем в листе. Массовая доля целлюлозы в целом составляет 48-53 \%, что свидетельствует об актуальности изучения биосинтеза бактериальной целлюлозы на питательной среде из растений M. sacchariflorus. Поскольку для технологических процессов, касающихся биосинтеза бактериальной целлюлозы, высокое содержание лигнина нежелательно, нами были проведены гистохимические исследования поперечных срезов соломин для определения сезонной динамики лигнификации. На основании полученных результатов предложено при установлении конкретных сроков заготовки надземной массы в качестве технологического сырья подтверждать их данными гистохимического анализа сезонной динамики лигнификации побегов M. sacchariflorus. Таким образом, изучение химического состава M. sacchariflorus, выращенного в климатических условиях Сибири, представило перспективность его использования с целью получения глюкозного субстрата - основного компонента доброкачественных питательных сред для биосинтеза бактериальной целлюлозы.

Ключевые слова: мискантус; Miscanthus sacchariflorus; онтогенез; химический состав; целлюлоза; бактериальная целлюлоза; гистохимический анализ.
\end{abstract}

\section{Introduction}

Nowadays, search for economically accessible and environmentally safe energy sources for multipurpose use is topical (Jones, 2001; Shumny et al., 2010; Dorogina et al., 2018; Schroder et al., 2018). Of special interest are fastgrowing herbaceous perennials that exhibit high gain of aboveground vegetative biomass, as they possess a number of ecological advantages over annual plants (Zhang et al., 2011; Iqbal et al., 2015). Alongside with common species, new plants, including Miscanthus, are being extensively put into practice.

Miscanthus, Miscanthus sacchariflorus (Maxim.) Hack., is a perennial, ecologically efficient crop with a high annual biomass gain of 10-15 t/ha over the span of 15-25 years (Slyn'ko et al., 2013; Bulatkin et al., 2015, 2017; Kapustyanchik et al., 2016; Gismatulina, Budaeva, 2017). Miscanthus features a special C4 photosynthetic pathway, which allows it to remain one of the most effective accumulators of solar energy, and ensures a high annual productivity even on badlands (Slyn'ko et al., 2013; Anisimov et al., 2016; Morandi et al., 2016; Xue et al., 2017).

In the context of the search for carbon sources to derive unique microbial synthesis products, Miscanthus sacchariflorus (Maxim.) Hack. can be a promising feedstock for good-quality nutrient media and specifically for biosynthesis of bacterial cellulose (BC). The features of this species grown in West Siberia include its ability to build up biomass within a short-term vegetative phase in the continental climate with short arid summer; frost-resistance; pest and disease resistance; and no need for fertilizers during the vegetative phase.

West Siberian forest steppe is a region of risky agriculture for many farm crops; thus, in choosing study methods, emphasis should be placed on overall stability, yielding capacity (fruit yield, seed yield, vegetative biomass yield), and feedstock quality. Besides, given the short vegetative phase, the plants of seed and vegetative origins demand that the durations of different ontogenetic states be assessed to reveal the most vulnerable ones.

Within the generic family of Miscanthus, which is studied at the Central Siberian Botanical Garden (CSBG) SB RAS and Institute for Problems of Chemical and Energetic Technologies (IPCET) SB RAS, the bioenergy resource species M. sacchariflorus is of special interest. As its domestication and screening of life-forms promising for breeding had been performed outside its native habitat and climatic zone, our efforts were focused on examining the full and reduced ontogenetic patterns, cellulose and noncellulosic contents, and on histochemical assays of duraminization in vegetative (feedstock source) organs during seasonal development.

Thus, the present study aimed to investigate the ontogeny, chemical composition, and duraminization in vegetative organs of $M$. sacchariflorus in the context of producing good-quality broths for subsequent microbiological synthesis of bacterial cellulose.

\section{Materials and methods}

The study was conducted with accessions of M. sacchariflorus (Maxim.) Hack. and, as developmental reference, M. sinensis Anderss. Plants of both species were sampled in the Russian Far East and introduced at the CSBG SB RAS in 2012. The developmental stages were identified using the periodization of ontogeny (Uranov, 1967, 1975; Plants Cenopopulations..., 1976, 1988) and studies on crop ontogeny (Ontogenetic Atlas..., 1997, 2013).

Chemical compositions were measured for the whole plant and for leaf and stem separately in seven Miscanthus harvests. For this purpose, Miscanthus was harvested annually within October 3 to 8 over the span of seven years, from 2011 to 2017. The aboveground part of the plant was cut 
off at 10-15 cm above the ground. After the plant was harvested, the rhizomes were left in soil to winter. Thus, the plantation was established once in 2011 and harvested many times (one year after the preceding harvest had been cut). Prior to the Miscanthus chemical composition analysis, the feedstock was dried to a humidity no more than $8 \%$ and chopped with scissors into 5-10-mm cuts.

The chemical composition was quantified as follows: Kürschner cellulose (a weighed sample treated with ethanolic $\mathrm{HNO}_{3}$ solution); pentosans were quantified by standard analytical procedures for raw materials (Obolenskaya et al., 1991) (a weighed sample was heated in $\mathrm{HCl}$ solution, and distilled furfural was assayed spectrometrically); ash content was quantified by incineration of the weighed sample in a porcelain crucible, followed by calcination of the residue in a muffle furnace; acid-insoluble lignin was assayed by TAPPI T222 om-83; and the wax-fat fraction (a weighed sample was extracted with methylene chloride, the extract was evaporated, and the nonvolatile residue was dried) was measured by TAPPI $204 \mathrm{~cm}-97$. The moisture content was determined on an OHAUS MB-25 moisture analyzer (USA). The chemical composition measurements were performed with equipment of the Biysk Regional Shared Access Center of Scientific Equipment of the SB RAS (IPCET SB RAS, Biysk).

For histochemical assays, we collected vegetative shoots in late August and dry shoots in late September past final vegetation of the plants that had earlier been brought in as live rhizomes from three natural populations in the Chuguyev and Khasan raions of Primorsky Krai. They were then grown under monotypic conditions as part of the Bioresource Scientific Collection of the CSBG SB RAS, USU No. 440534. For analysis, 10-cm long stem samples were taken at the minimum industrial height $10 \mathrm{~cm}$ above the ground level.

Further studies were conducted at the Shared Access Center of Scientific Equipment, CSBG SB RAS. The shoots were cut lengthwise with a scalpel into bars of about $3 \mathrm{~mm}$ and placed into a freezing microtome to make longitudinal sections of $60-90 \mu \mathrm{m}$. The samples were stained with phloroglucinol by the standard procedure (Barykina et al., 2004). Microscopic photos were taken with a Carl Zeiss Axio Scope A1 optical microscope.

\section{Results}

The ontogenetic features of $M$. sacchariflorus were examined against the other species, $M$. sinensis, as these species have different biomorphs in their native habitats in Primorsky Krai. Investigation of the genesis of a plant life-form during development under new growing conditions allows a set of growing methods to be devised and optimum time limits for feedstock preparation to be identified.

Since the literature lacks data on the ontogenetic features of the genus Miscanthus, we were first to investigate comprehensively the ontogeny of M. sacchariflorus specimens versus $M$. sinensis. The enforced nondeep dormancy of $M$. sacchariflorus seeds was found to constitute the latent stage. The caryopses were very small, 2.3 to $2.6 \mathrm{~mm}$ long, narrow ellipsoidal and loose, and the germ was one-half as long as the seed.

Pregenerative stage. When sown under lab-scale conditions, the seeds produced shoots on day 3 or 4 . The vigor and germinating capacity of freshly collected (in native habitats) seeds were very high, 80.0-85.5\%. The seedlings had a primary shoot and an embryo root. Second leaves appeared after seven days. Further formation of next leaves suspended, whereas the root system composed of secondary roots was intensely developing. The plants remained in the seedling state for a long time, up to 2.5 months.

The juvenile plants lost the contact with the caryopsis. The primary sprout and the roots remained and developed further. The plants had 9 or 10 green assimilating leaves, and they were smaller and narrower than those of adult plants. The M. sinensis scale-like leaves were tightly adjacent to the base of the shoot. This $a$

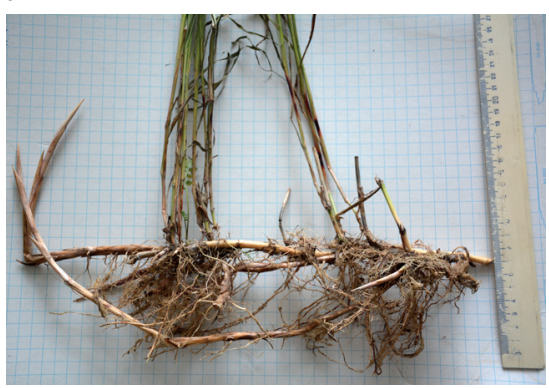

$b$

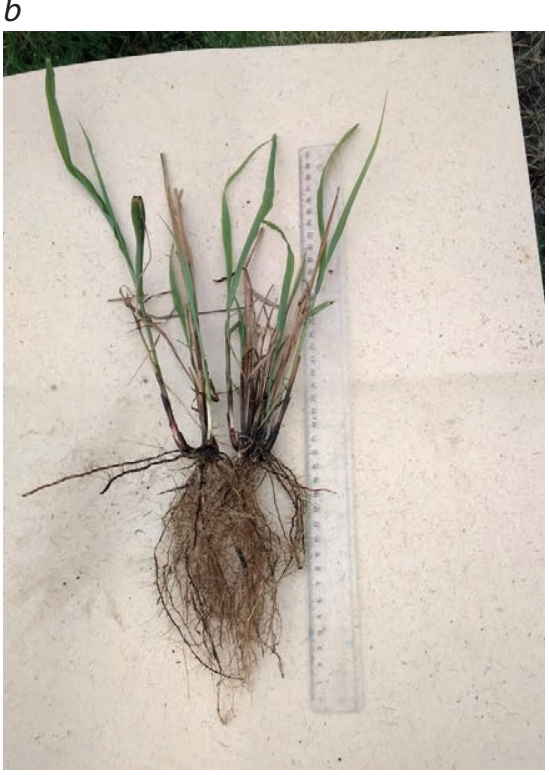

Fig. 1. Rhizome fragments of immature plants: $a-$ Miscanthus sacchariflorus (Maxim.) Hack.; $b$ - Miscanthus sinensis Anderss.

state lasted more than two months. It should be noted that the seedlings and plantlets were in a greenhouse prior to the vegetative phase.

The shoot and root systems of immature plants (Fig. 1, $a, b$ ) acquired signs of transition from juvenile to adult. The type of leaves was also transitional: they rapidly grew and increased in length and width. The basic diagnostic marker sign of this state in cereals was that plants entered the tillering stage. The bottom leaves obliqued from the stem, assumed the horizontal position, and died off, exposing intravaginal lateral shoots. The shoot formation in $M$. sacchariflorus was more intense (see Fig. 1, a) (which, later on, would allow it to build up vegetative biomass), and lateral shoots totaling 2-3 developed, whereas $M$. sinensis had only one 
lateral shoot (Fig. 1, b). This ontogenetic state lasted 4-4.5 months.

Virginile plants. The sod diameter of virginile $M$. sinensis plants was considerably smaller than in $M$. sacchariflorus (15-20 vs. 25-30 cm, respectively). The plants had adult-type stems, leaves and roots. The lateral shoots were fast to develop, keeping up with the primary shoot in height. The bottom leaves of the primary shoot died off, and by that time the green assimilating leaves numbered 7-9. The life forms typical of adult plants were noted to establish ( $M$. sinensis: a perennial, summer-green, grassy, short-rhizome, loose-sod, sympodially accrescent polycarpic plant with a semi-rosulate upright shoot and M. sacchariflorus: a perennial, summer-green, grassy, thin-long-rhizome, sympodially accrescent, polycarpic plant with an elongated upright shoot ). Most of the plants had no generative shoots. In September, by the end of the vegetative stage of the first life year, the plants produced 8 to 20 shoots. The average number of shoots per plant exceeded 10, and the average plant height was $57.5 \mathrm{~cm}$. The root system was well developed, with the length exceeding $15 \mathrm{~cm}$.

Occasional samples passed to the generative stage, the $\mathrm{G} 1$ phase. Yet the young generative plants formed only one generative shoot each, on which seeds did not ripen. However, this fact had earlier been ascertained for Miscanthus in the continental climate of West Siberia forest steppe and attributed to temperatures too low for the formation of seeds in October, as opposed to the monsoon climate of southern Primorsky Krai.

Thus, this study into the features of the full ontogeny in plants grown from seeds collected in native habitats demonstrated that the specimens of the two Miscanthus species are distinguished by longer being in the most vulnerable ontogenetic states, seedlings and plantlets.

By expert evidence, a feedstock that is abundant, available, annually renewable, low-cost, highly ecologically effective, and storable will become a major raw material for many biotechnological industries in the nearest future (Mussatto et al., 2010). Miscanthus meets these criteria completely.

The study of the chemical composition of M. sacchariflorus grown in Siberia would allow one to evaluate the expediency of its processing for BC biosynthesis. Bacterial cellulose is an organic nanomaterial produced extracellularly by microorganisms under static (on the culture medium surface) or dynamic (agitated) conditions. Diverse nutrient media for BC culturing have been reported (Goelzer et al., 2009; Hong et al., 2012; Chen et al., 2013; Sakovich et al., 2017; Velásquez-Riaño, Bojacá, 2017; Revin et al., 2018; Hussain et al., 2019), and food-industry waste and agricultural residues are reckoned among preferential ones. The global trend is to substantiate the use of low-cost nutrient media for BC synthesis. However, it is seldom that Miscanthus is enlisted among potential nutrient media. Table summarizes the chemical compositions of seven $M$. sacchariflorus harvests: the whole plant, leaf and stem separately.
The contents of chemical elements in different plant organs are known to be variable and dependent on the plant species and age, regional climatic features, seasonal development, and forest growth conditions in the habitats (Torlopova, Robakidze, 2012). The Miscanthus biomass yield also depends on many factors: genotype, soil type, nutrients applied, plantation age, bioclimatic location, and weather during the agricultural season (Brosse et al., 2012).

The studies on the relationship between the chemical composition and plant age by the example of three harvests (2-, 3- and 4-year old plantations) revealed no considerable changes in any constituent except ash (Allison et al., 2011; Arnoult, Brancourt-Hulmel, 2015). In addition, the chemical compositions of different morphological parts of the plant were reported in (Krotkevich et al., 1983; Bergs et al., 2019). However, those studies were conducted in the temperate climate rather than in extremely continental Siberia. Therefore, investigation of the effects of plantation age and morphological part on the chemical composition of Miscanthus bred in Siberia remains highly relevant.

By the example of seven $M$. sacchariflorus harvests (see Table), chemical composition was found to depend not only on the plant age but also on plant morphology. The whole Miscanthus plant contained 41.7-53.6\% Kürschner cellulose, 3.2-6.3\% ash content, 20.1-23.8\% acid-insoluble lignin, 18.6-25.3\% pentosans, and 2.8$5.7 \%$ fat-wax. The findings are consistent with the data reported for different Miscanthus genotypes in terms of the major constituents, cellulose and lignin (Jones, Walsh, 2001; Somerville et al., 2010; Brosse et al., 2012). The fat-wax fraction exceeds the values reported overseas, 0.5-0.6\% (Villaverde et al., 2009).

According to these literature reports, the major constituents of Miscanthus are cellulose (40-60\%), which forms the plant framework; hemicellulose (20$40 \%$ ), which is a matrix substance consisting of different polysaccharides; and lignin, which provides the structural rigidity and integrity (10-30\%). We found that the cellulose content increased and the noncellulosic content decreased with plantation age. A substantial growth in cellulose content was observed from the first $(41.7 \%)$ to the fifth $(53.6 \%)$ life year of the plantation, a nearly $12 \%$ increase. Past the five-year age of the plantation, no significant increment in cellulose content was noticed; the cellulose content of $50 \%$ remained stable over two years (Miscanthus harvests from plantations aged 6 and 7 years). Thus, 5-year-old Miscanthus was found to have the highest cellulose content, $53.6 \%$.

Among noncellulosic ingredients, high lignin content has an adverse effect during pretreatment of the feedstock for subsequent biosynthesis of BC. Therefore, lignin, which provides structural rigidity and integrity, should be controlled. In this regard, histochemical assays of transverse sections of the culms were performed to determine the seasonal course of lignification.

Representatives of the genus Miscanthus pertain to monocotyledon plants of the Poaceae family, most of 
Chemical compositions of seven M. sacchariflorus harvests: whole plant, leaf and stem separately

\begin{tabular}{|c|c|c|c|c|c|c|}
\hline \multirow{2}{*}{$\begin{array}{l}\text { Harvest year, } \\
\text { plantation age }\end{array}$} & \multirow{2}{*}{$\begin{array}{l}\text { Morphological part } \\
\text { of Miscanthus }\end{array}$} & \multicolumn{5}{|l|}{ Content ${ }^{*}, \%$} \\
\hline & & Kürschner cellulose & Ash & Lignin & Pentosans & $\begin{array}{l}\text { Wax-fat } \\
\text { fraction }\end{array}$ \\
\hline \multirow{3}{*}{$\begin{array}{l}2011, \\
1 \text { year }\end{array}$} & Whole plant & 41.7 & 6.3 & 22.2 & 25.3 & 5.7 \\
\hline & Leaf & 38.7 & 11.5 & 23.9 & 20.7 & 7.7 \\
\hline & Stem & 48.1 & 3.0 & 20.5 & 27.9 & 4.3 \\
\hline \multirow{3}{*}{$\begin{array}{l}2012 \\
2 \text { years }\end{array}$} & Whole plant & 44.5 & 6.2 & 23.8 & 23.6 & 4.8 \\
\hline & Leaf & 40.5 & 8.7 & 25.3 & 20.7 & 6.1 \\
\hline & Stem & 50.2 & 2.1 & 18.4 & 26.6 & 4.0 \\
\hline \multirow{3}{*}{$\begin{array}{l}2013, \\
3 \text { years }\end{array}$} & Whole plant & 47.8 & 4.6 & 21.1 & 25.1 & 2.8 \\
\hline & Leaf & 43.7 & 7.5 & 23.9 & 20.8 & 4.6 \\
\hline & Stem & 50.7 & 2.0 & 17.2 & 27.4 & 1.8 \\
\hline \multirow{3}{*}{$\begin{array}{l}2014, \\
4 \text { years }\end{array}$} & Whole plant & 53.1 & 5.9 & 22.0 & 21.0 & 5.0 \\
\hline & Leaf & 43.3 & 9.2 & 23.6 & 20.3 & 6.3 \\
\hline & Stem & 55.7 & 2.1 & 14.9 & 23.0 & 2.7 \\
\hline \multirow{3}{*}{$\begin{array}{l}2015 \\
5 \text { years }\end{array}$} & Whole plant & 53.6 & 3.6 & 20.1 & 18.6 & 3.6 \\
\hline & Leaf & 43.6 & 6.7 & 22.8 & 17.0 & 6.1 \\
\hline & Stem & 56.6 & 2.2 & 16.0 & 20.9 & 2.1 \\
\hline \multirow{4}{*}{$\begin{array}{l}2016, \\
6 \text { years }\end{array}$} & Whole plant & 50.1 & 3.2 & 22.3 & 20.4 & 4.5 \\
\hline & Leaf & 43.8 & 9.9 & 26.6 & 19.5 & 6.7 \\
\hline & Stem & 55.9 & 1.7 & 18.9 & 21.5 & 2.5 \\
\hline & Whole plant & 50.2 & 5.1 & 23.1 & 20.4 & 4.9 \\
\hline \multirow{2}{*}{$\begin{array}{l}2017 \\
7 \text { years }\end{array}$} & Leaf & 45.2 & 7.5 & 27.2 & 19.5 & 5.7 \\
\hline & Stem & 53.6 & 1.5 & 18.7 & 22.5 & 3.1 \\
\hline
\end{tabular}

* On an oven-dry basis.

which possess closed fiber vascular bundles scattered over the entire stem thickness. The constitution of the Miscanthus stem is close to that in rye and barley: parenchymal cells and vascular bundles gravitate to the periphery (Fig. 2, a).

The bundles are interspaced with the basic parenchyma tissue. Under epidermis, one can clearly see a rich pink ring of sclerenchyma, which imparts strength to the culm, partly owing to gradual duraminization. It is lignification that hinders feedstock treatment and pulping. In Fig. 2, $b$, the cells and tissues having a pink color of different intensity are stained with phloroglucinol, which exposes the extent of duraminization. Each fiber vascular bundle is made up of xylem vessels surrounded by woody parenchyma and of phloem and sclerenchymatous fibers. It is seen in Fig. 2, $b$ that the bundle sheath exhibits a high level of duraminization as well.
It should be noted, though, that those sections were made upon completion of the vegetative stage, when the lignification process was the most pronounced in all tissues. The studies done at an earlier stage of feedstock preparation (see Fig. 2, c) showed that culm duraminization was at the initial stage.

\section{Discussion}

The study into the features of full ontogeny in plants grown from seeds that had been collected in native habitats demonstrated that the accessions of both Miscanthus species are distinguished by longer duration of the most vulnerable ontogenetic states: seedlings and plantlets. It can thus be inferred that the seed propagation method is of interest when working with a breeding material in good agricultural conditions, including cultivation of seedlings in protected ground. Industrial and pilot plantations should 

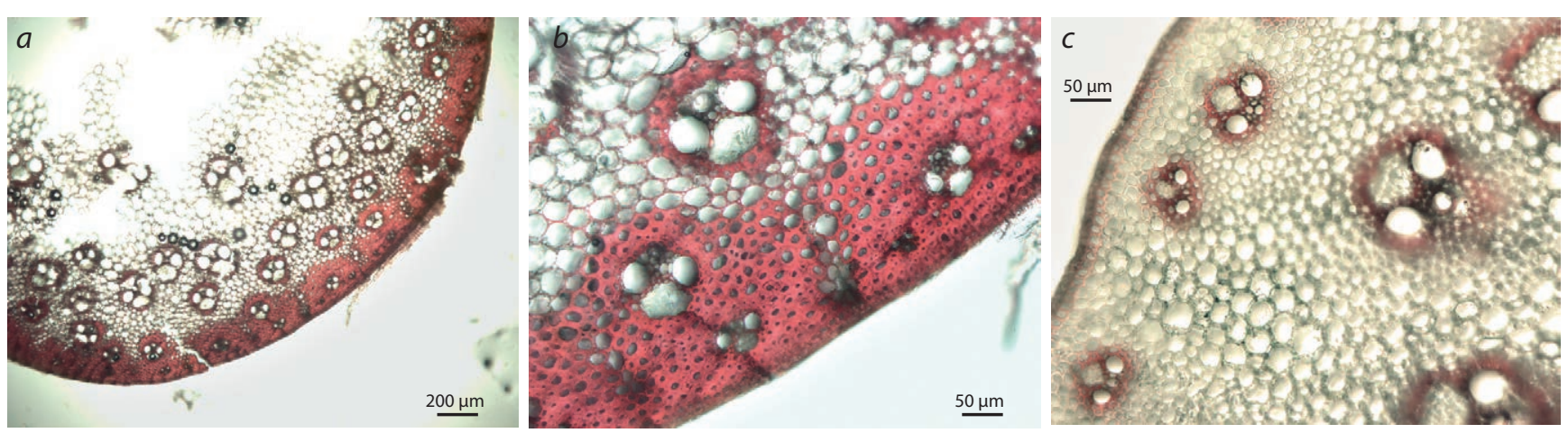

Fig. 2. Anatomical structure of the transverse section of Miscanthus sacchariflorus (Maxim.) Hack. stem: (a) typical (general view), (b) in late September, (c) in late August.

be established with cloned vegetative material, which is more stable.

The analyses of the chemical compositions of whole M. sacchariflorus plants and of leaves and stems separately form seven harvests showed that the cellulose content increased and the noncellulosic content decreased with plantation age. Beyond the 5-year age of the plantation, no growth in the cellulose mass fraction was observed. The cellulose content within 50.2-53.6 \% indicates that this Miscanthus species is a promising cellulosic resource. We infer therefrom that it is more advisable to use a mature plant for the processing, as the cellulose yield is higher in this case. Generally, Miscanthus plantations aged 4-7 years exhibited high cellulose contents, and they are preferable for different chemical and biotechnological conversions.

The rise in cellulose percentage in the whole plant throughout five years is due to the fact that the Miscanthus seedling density becomes larger year after year, while the contribution of leaves, containing less cellulose, declines.

Irrespective of the plantation age, the highest cellulose content was found in the Miscanthus stem (48.1-56.6 \%) and in the leaf it was $38.7-45.2 \%$. Despite the earlier recommendations given for different Miscanthus genotypes (Brosse et al., 2012), it was found herein that it is most advisable to use the Miscanthus stem in order to obtain a higher yield of cellulose and/or glucose. The prevailing content of cellulose in cereal crop stems is reported for wheat straw, oat, barley and rice (Lengyel, Morvay, 1973; Sun, 2010).

The histochemical assay revealed that since the transverse sections were made after the vegetative phase was completed, lignification was predominant in all tissues. The data on earlier feedstock preparation (see Fig. 2, c) demonstrated that culm duraminization was at the initial stage in August. As the hydrothermal conditions of the vegetative phases in terms of plant introduction vary considerably from year to year, we suggest here for the first time that the histochemical assay of the seasonal course of lignification of Miscanthus shoots be performed annually in determining specific time limits for the harvesting of aboveground biomass as the feedstock.

\section{Conclusion}

Thus, the analysis of the chemical composition of M. sacchariflorus grown in the Siberian climate demonstrated its high potential in the production of glucose substrate as the basic component of nutrient broths for biosynthesis of bacterial cellulose. The suggestion is innovative. It reduces the need for food-grade carbon sources for microbiological transformation.

Our findings prove the high relevance of the study into bacterial cellulose biosynthesis in a nutrient medium derived from $M$. sacchariflorus, the science-based engineering solution in the bacterial cellulose technology. Miscanthus, producing much cellulose, $48-53 \%$ of the biomass, has a great resource potential for the manufacture of bacterial cellulose. Further studies are required for the most efficient solution of key technological issues. These issues include the development of cost-effective modes of chemical pretreatment and enzymatic hydrolysis of Miscanthus in a high glucose yield, enabling the use of such a glucose nutrient broth for bacterial cellulose synthesis.

\section{References}

Allison G.G., Morris C., Clifton-Brown J., Lister S.J., Donnison I.S. Genotypic variation in cell wall composition in a diverse set of 244 accessions of Miscanthus. Biomass Bioener. 2011;35(11):4740-4747. DOI 10.1016/j.biombioe.2011.10.008.

Anisimov A.A., Khokhlov N.F., Tarakanov I.G. Miscanthus (Miscanthus spp.) in Russia: opportunities and prospects. Novye i Netraditsionnye Rasteniya i Perspektivy ikh Ispolzovaniya $=$ New and Unconventional Plants and their Application Prospects. 2016;12:3-5. (in Russian) 
Arnoult S., Brancourt-Hulmel M. A review on Miscanthus biomass production and composition for bioenergy use: Genotypic and environmental variability and implications for breeding. BioEnergy Res. 2015;8:502-526. DOI 10.1007/s12155-014-9524-7.

Barykina R.P., Veselova T.D., Devyatov A.G., Dzhalilova Kh.Kh., Il'ina G.M., Chubatova N.V. Handbook of Botanical Microtechniques. Basics and Methods. Moscow, 2004. (in Russian)

Bergs M., Völkering G., Kraska T., Pude R., Tung X.D., Kusch P., Monakhova Yu., Konow C., Schulze M. Miscanthus $\times$ giganteus stem versus leaf-derived lignins differing in monolignol ratio and linkage. Int. J. Mol. Sci. 2019;20(5):1200. DOI 10.3390/ijms20051200.

Brosse N., Dufour A., Meng X., Sun Q., Ragauskas A. Miscanthus: a fast-growing crop for biofuels and chemicals production. Biofuels Bioprod. Bioref. 2012;6(5):580-598. DOI 10.1002/bbb.1353.

Bulatkin G.A., Mitenko G.V., Guriev I.D. Energy and ecological efficiency of growing Chinese silver grass (Miscanthus sinensis Anderss.) in central federal district of Russia. Ispolzovanie i Okhrana Prirodnykh Resursov v Rossii = Natural Resource Management and Conservation in Russia. 2015;6(144):39-45. (in Russian)

Bulatkin G.A., Mitenko G.V., Guriev I.D. Alternative power engineering: vegetation materials as new resources. Teoreticheskaya i Prikladnaya Ekologiya = Theoretical and Applied Ecology. 2017;2: 88-92. (in Russian)

Chen L., Hong F., Yang X.X., Han S.F. Biotransformation of wheat straw to bacterial cellulose and its mechanism. Bioresour. Technol. 2013;135:464-468. DOI 10.1016/j. biortech.2012.10.029.

Dorogina O.V., Vasilyeva O.Yu., Nuzhdina N.S., Buglova L.V., Gismatulina Yu.A., Zhmud E.V., Zueva G.A., Komina O.V., Tsybchenko E.A. Resource potential of some species of the genus Miscanthus Anderss. under conditions of continental climate of West Siberian foreststeppe. Vavilovskii Zhurnal Genetiki I Selektsii = Vavilov Journal of Genetics and Breeding. 2018;22(5):553-559. (in Russian)

Gismatulina Yu.A., Budaeva V.V. Chemical composition of five Miscanthus sinensis harvests and nitric-acid cellulose therefrom. Ind. Crop. Prod. 2017;109:227-232. DOI 10.1016/j.indcrop.2017. 08.026.

Goelzer F.D.E., Faria-Tischer P.C.S., Vitorino J.C., Sierakowski M.R., Tischer C.A. Production and characterization of nanospheres of bacterial cellulose from Acetobacter xylinum from processed rice bark. Mater. Sci. Eng. 2009;29:546-551. DOI 10.1016/j.msec.2008. 10.013.

Hong F., Guo X., Zhang S., Han S., Yang G., Jonsson L.J. Bacterial cellulose production from cotton-based waste textiles: enzymatic saccharification enhanced by ionic liquid pretreatment. Bioresour. Technol. 2012;104:503-508. DOI 10.1016/j.biortech.2011.11.028.

Hussain Z., Sajjad W., Khan T., Wahid F. Production of bacterial cellulose from industrial wastes: a review. Cellulose. 2019;26(5):2895-2911. DOI 10.1007/s10570-019-02307-1.
Iqbal Y., Gauder M., Claupein W., Graeff-Honninger S., Lewandowski I. Yield and quality development comparison between miscanthus and switchgrass over a period of 10 years. Energy. 2015;89:268-276. DOI 10.1016/j. energy.2015.05.134.

Jones M.B., Walsh M. Miscanthus: For Energy and Fibre. London: James \& James, 2001.

Kapustyanchik S.Yu., Likhenko I.E., Danilova A.A. Productivity of Miscanthus variety Soranovskiy of the first year of vegetation and soil respiratory activity. Permskiy Agrarnyy Vestnik = Perm Agrarian Journal. 2016;4(16):8287. (in Russian)

Krotkevich P.G., Shumejko K.I., Voloshina L.A., Nesterchuk E.N., Petrun' I.I. Morphological features and chemical composition of Miscanthus sinensis Anderss. as a feedstock for pulp and paper industry. Rastitelnye Resursy = Plant Resources. 1983;19(3):321-323. (in Russian)

Lengyel P., Morvay S. Chemie und Technologie der Zellstoffherstellung. Budapest: Akademiai Kiado, 1973.

Morandi F., Perrin A., Østergård H. Miscanthus as energy crop: Environmental assessment of a miscanthus biomass production case study in France. J. Clean. Prod. 2016;137:313-321. DOI 10.1016/j.jclepro.2016.07.042.

Mussatto S.I., Dragone G., Guimaraes P.M.R., Silva J.P.A., Carneiro L.M., Roberto I.C., Vicente A., Domingues L., Teixeira J.A. Technological trends, global market, and challenges of bio-ethanol production. Biotechnol. Adv. 2010;28:817-830. DOI 10.1016/j. biotechadv.2010.07.001.

Obolenskaya A.V., El’nickaya Z.P., Leonovich A.A. Laboratory Course on the Chemistry of Wood and Cellulose. Moscow, 1991. (in Russian)

Ontogenetic Atlas of Medicinal Plants. Yoshkar-Ola: Mari State University, 1997. (in Russian)

Ontogenetic Atlas of Plants. Yoshkar-Ola: Mari State University, 2013. (in Russian)

Plant Cenopopulations: Basic Concepts and Structure. Moscow, 1976. (in Russian)

Plant Cenopopulations: Population Biology Essays. Moscow, 1988. (in Russian)

Revin V.V., Liyaskina E.V., Nazarkina M.I., Bogatyreva A.O., Shchankin M.V. Cost-effective production of bacterial cellulose using acidic food industry by-products. Braz. J. Microbiol. 2018;49(1):151-159. DOI 10.1016/j. bjm.2017.12.012.

Sakovich G.V., Skiba E.A., Budaeva V.V., Gladysheva E.K., Aleshina L.A. Technological fundamentals of bacterial nanocellulose production from zero prime-cost feedstock. Dokl. Biochem. Biophys. 2017;477(1):357-359. DOI 10.1134/S1607672917060047.

Schroder P., Beckers B., Daniels S., Gnädinger F., Maestri E., Marmiroli N., Menchd M., Millan R., Obermeier M.M., Oustriere N., Persson T., Poschenrieder C., Rineau F., Rutkowska B., Schmid T., Szulc W., Witters N., Sæbø A. Intensify production, transform biomass to energy and novel goods and protect soils in Europe - A vision how to mobilize marginal lands. Sci. Total Environ. 2018;616617:1101-1123. DOI 10.1016/j.scitotenv.2017.10.209. 
Shumny V.K., Kolchanov N.A., Sakovich G.V., Parmon V.N., Veprev S.G., Nechiporenko N.N., Goryachkovskaya T.N., Bryanskaya A.V., Budaeva V.V., Zheleznov A.V., Zheleznova N.B., Zolotukhin V.N., Mitrofanov R.Yu., Rozanov A.S., Sorokina K.N., Slynko N.M., Yakovlev V.A., Peltek S.E. Search for renewable sources of multi-purpose cellulose. Informatsionnyy Vestnik VOGiS = The Herald of Vavilov Society for Geneticists and Breeding Scientists. 2010;14(3):569-578. (in Russian)

Slynko N.M., Goryachkovskaya T.N., Shekhovtsov S.V., Bannikova S.V., Burmakina N.V., Starostin K.V., Rozanov A.S., Nechiporenko N.N., Veprev S.G., Shumny V.K., Kolchanov N.A., Peltek S.E. The biotechnological potential of the new crops, Miscanthus cv. Soranovskii. Vavilovskii Zhurnal Genetiki i Selektsii = Vavilov Journal of Genetics and Breeding. 2013;17(4/1):765-771. (in Russian)

Somerville C., Youngs H., Taylor C., Davis S.C., Long S.P. Feedstocks for lignocellulosic biofuels. Science. 2010;329:790-792. DOI 10.1126/science.1189268.

Sun R.C. Cereal Straw as a Resource for Sustainable Biomaterials and Biofuels: Chemistry, Extractives, Lignins, Hemicelluloses and Cellulose. Oxford: Elsevier, 2010.

Torlopova N.V., Robakidze E.A. Chemical composition of pine needles under the influence of aerial technogenic pollution from the Syktyvkar Timber Industry Complex. Sibirskiy Ekologicheskiy Zhurnal = Siberian Journal of Ecology. 2012;5(3):307-313. (in Russian)

Uranov A.A. Ontogenesis and age composition of populations. Ontogenesis and the Age Composition of Flowering Plant Populations. Moscow, 1967;3-8. (in Russian)

Uranov A.A. Age spectrum of phytocenopopulations as a function of time and energy wave processes. Biologicheskie Nauki = Biological Sciences. 1975;2:7-34. (in Russian)

Velásquez-Riaño M., Bojacá V. Production of bacterial cellulose from alternative low-cost substrates. Cellulose. 2017;24:2677-2698. DOI 10.1007/s10570-017-1309-7.

Villaverde J.J., Domingues R.M.A., Freire C.S.R., Silvestre A.J.D., Pascoal Neto C., Ligero P., Vega A. Miscanthus $\times$ giganteus extractives: a source of valuable phenolic compounds and sterols. J. Agric. Food Chem. 2009;57:3626-3631.

Xue S., Lewandowski I., Kalinina O. Miscanthus establishment and management on permanent grassland in southwest Germany. Ind. Crop. Prod. 2017;108:572-582.

Zhang Y., Li Y., Jiang L., Tian C., Li J., Xiao Z. Potential of perennial crop on environmental sustainability of agriculture. Proc. Environ. Sci. 2011;10:1141-1147.

ORCID ID

Y.A. Gismatulina orcid.org/0000-0001-5480-7449

V.V. Budaeva orcid.org/0000-0002-1628-0815

G.V. Sakovich orcid.org/0000-0001-6208-2329

O.V. Dorogina orcid.org/0000-0001-5729-3594

Acknowledgements. The study was supported by the Russian Science Foundation, project No.17-19-01054. Use was made of the materials of the bioresource scientific "Collection of Live Plants in Open and Protected Grounds", USU 440534.

Conflict of interest. The authors declare no conflict of interest.

Received June 18, 2019. Revised July 25, 2019. Accepted August 9, 2019. 